20. Mishra, S., Mazumdar, S. and Suar, D., Place attachment and flood preparedness. J. Environ. Psychol., 2010, 30(2), 187-197.

21. Fernandes, W., Look (act) East policy: with or through the Northeast. In Mainstreaming the Northeast in India's Look and Act East Policy, Palgrave Macmillan, Singapore, 2018, pp. 233-251.

22. Tripathi, P., Tribes and forest: a critical appraisal of the tribal forest right in India. Res. J. Soc. Sci. Manage., 2016, 6(6), 1-8.

23. Singh, B. P., Biodiversity, tribal knowledge and life in India. Environ. Soc. Psychol., 2017, 2(1), 1-10.

24. Chaudhry, P., Dollo, M., Bagra, K. and Yakang, B., Traditional biodiversity conservation and natural resource management system of some tribes of Arunachal Pradesh, India. Interdiscip. Environ. Rev., 2011, 12(4), 338-348.

25. Das, S., and Das, M., Shifting cultivation in Tripura - a critical analysis. J. Agric. Life Sci., 2014, 1(1), 48-54.

26. Lombi, P., People's perception about shifting cultivation - with special reference to the Galo tribe of West Siang District, Arunachal Pradesh (India). Int. J. Sci. Res. Publ., 2016, 6(7), 454-459.

27. Sangma, R. C., Festivals and ceremonies of Garo. Garo J., 2018; https://garojournal.com/festivals-ceremonies-garos/ (accessed on 23 October 2018)

28. Teegalapalli, K. and Datta, A., Shifting to settled cultivation: changing practices among the Adis in central Arunachal Pradesh. North-East India. Ambio, 2016, 45(5), 602-612.

29. Chapin III, F. S. (eds). Arctic Ecosystems in a Changing Climate: An Ecophysiological Perspective, Academic Press, San Diego, California, 2012.

30. Raymond, C. M. et al., Ecosystem services and beyond: using multiple metaphors to understand human-environment relationships. BioScience, 2013, 63(7), 536-546.

ACKNOWLEDGEMENTS. This study was conducted as part of the project 'Mapping of socio-economic and livelihood patterns of Jhumias in North Eastern Hill Region of India', funded by the Indian Council of Agricultural Research, New Delhi. We thank all the respondents, tribals and key informants for their cooperation.

Received 19 November 2018; accepted 10 January 2019

\section{Did Romans have direct maritime trade contacts with Odisha on the Eastern Indian littoral?}

\author{
Sila Tripati* and Rudra Prasad Behera \\ CSIR-National Institute of Oceanography, Dona Paula, \\ Goa 403 004, India
}

Kalinga, Utkal, Odra and Orissa are former names of the present state of Odisha with varied geographical boundaries in different periods of history. The exploration and excavations of Manikapatna, Palur, Radhanagar, Sisupalgarh, Talapada of Odisha have

\footnotetext{
*For correspondence. (e-mail: sila@nio.org)
}

brought to light terracotta Roman bullae with Roman portraits, lamps, amphorae shreds and rouletted ware which suggested that these findings belong to the Roman period (early centuries of Christian era) and Roman mariners had maritime contacts with Odisha from the early historical period onwards, if not earlier. However, it is evident that Roman artefacts such as gold coins, amphorae, Terra Sigillata (Arretine ware), etc., are more abundant in peninsular India than in the rest of the country and these findings are limited in Odisha, but the reasons are not comprehensible. However, archaeological findings from the port and trade centres delineate maritime contacts of Odisha with Southeast Asian countries. Here we discuss the archaeological findings from the port sites of Odisha to understand the maritime contacts with Southeast Asian countries and the Roman Empire and examine why the Roman findings are comparatively less in Odisha than in peninsular and other parts of India.

Keywords: Odisha, maritime trade, ports, Romans, Southeast Asia.

THE recorded history of Odisha, east coast of India, starts from the 3 rd century BCE onwards. In the annals of history, Odisha has been referred to as Udra or Odra Desa, Kalinga, Utkal, Orissa; now it has been renamed as Odisha. Archaeological findings, epigraphic, sculptural, literary and art evidence corroborate the maritime contacts of Odisha with Southeast Asian countries and the Roman Empire. However, the contacts between Odisha and Southeast Asia are more evident compared with those of the Roman Empire. Earlier studies ${ }^{1-5}$ suggest maritime contacts of Odisha with the Roman empire, Roman findings in Odisha, etc. Therefore, it is crucial to understand whether Odisha had direct trade contacts with the Roman Empire or not, and why the Roman findings are very limited in Odisha compared with peninsular India. As a result, in this study, the archaeological findings such as different types of pottery, amphorae, Roman coins, etc., found from ports and settlement sites of Odisha and neighbourhood are examined to understand the contacts between Odisha and the Roman Empire. An attempt has also been made to understand the reasons why Roman findings were limited in Odisha.

In the Indian Ocean maritime trade, during the early historical period, a wide variety of pottery was recorded from ports and trade centres along the east and west coasts of India. Pottery is a well preserved cultural material which can be traced along with other maritime trade materials, and it was one of the objects and medium used for the trade. The early historical period pottery namely Northern black polished ware (NBPW), rouletted ware (RW), knobbed ware (KW), stamped ware, amphorae and other artefacts were transported both by land and water routes. The discovery of identical pottery from a number 


\section{RESEARCH COMMUNICATIONS}

of sites suggests regional and overseas trade and cultural contacts among the people and the existence of routes. All these ceramics are datable to the early centuries of the Common Era to the 3rd-4th centuries CE.

The first discoveries of NBPW were from Bhita, Sarnath and Taxila ${ }^{6-8}$. Before it was denoted as NBPW, it was known as black lustrous ware, the Greek black ware. Recent excavations at Ayodhya have yielded NBPW which is datable to $1000 \mathrm{BCE}$ (ref. 9). NBPW has been reported from many coastal sites of West Bengal, Odisha, Andhra Pradesh, Tamil Nadu, Kerala, Maharashtra and inland sites of northern India (Figure 1). This ware was made of fine clay of the Gangetic valley, thin in fabric, well-fired, and grey to reddish coloured with a mirrorlike thin film polish. The other significant aspect is that NBPW and punch marked coins (PMC) have been reported from excavations in the citadel of Anuradhapura and other Buddhist sites of Sri Lanka ${ }^{10,11}$. However, except Sri Lanka, NBPW is not reported from any other place of Southeast Asia and the Roman empire. During the NBPW period, significant progress was noticed in the technological skill and development of cities. The finding of NBPW along coastal and hinterland Buddhist establishments suggests the involvement of Buddhism in maritime trade network and linkages with traders as well as money-based economy ${ }^{7,12}$. The Buddhist monks and royal houses used NBPW because of its excellence and endurance.

RW is fine textured with rouletted designs such as parallelograms or diamonds, dots, triangles and wedges

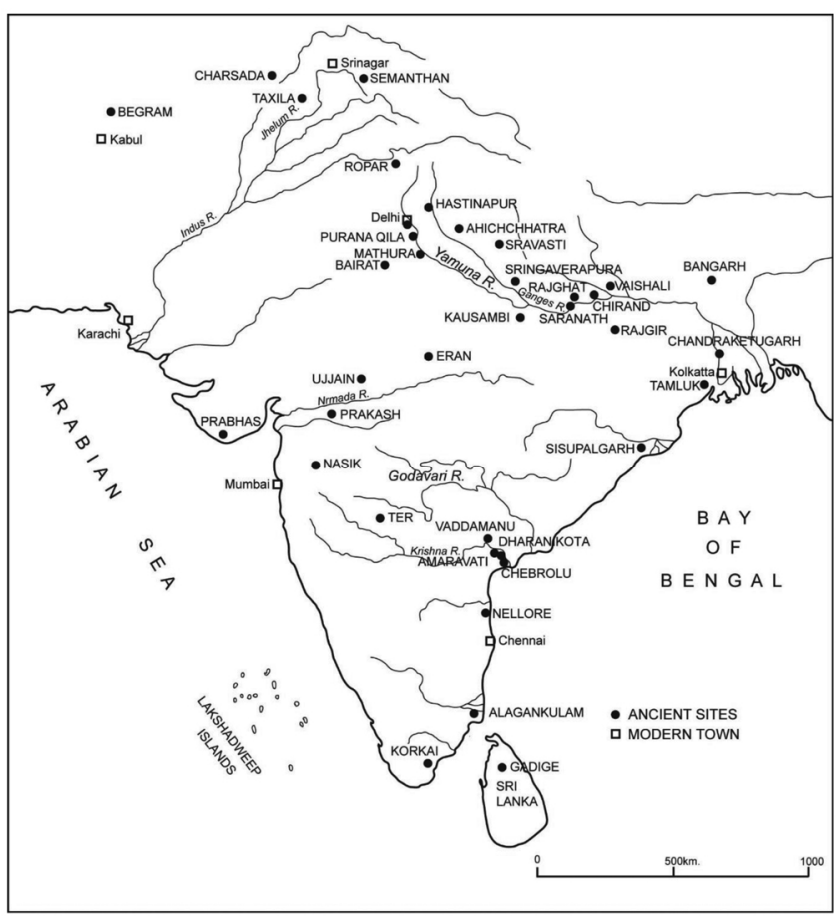

Figure 1. Northern black polished ware sites of India. found on the base of the pottery. It was believed that RW was used on special occasions for offerings but not for daily usages; evidences show that RW was used for consuming food found in trench XIII of Arikamedu excavations in 1989-92 where as RW plate was discarded with chicken bones. This pottery has been reported from more than a hundred sites all over India (Figure 2). Majority of the sites are along the east coast of India and across the Bay of Bengal, namely from Sri Lanka ${ }^{13-15}$, Bangla$\operatorname{desh}^{16,17}$, Myanmar, Java, Sumatra, Bali ${ }^{18}$, Thailand ${ }^{19}$, Vietnam, Malaysia, Yemen and $\mathrm{Oman}^{20-25}$, Myos Hormos, Berenike and Coptos in Egypt ${ }^{26,27}$. Moreover, RW sherds with Brahmi, Tamil-Brahmi, Sri Lankan Brahmi, Kharoshti inscriptions and graffito marks have also been recovered from several sites in India and abroad $^{28}$. It is believed that these graffito marks and inscriptions could be the names of the traders or pot makers.

Generally, a boss or projection is found at the centre of the base of the KW along with and without concentric circles. Different fabrics of KW have been reported such as fine grey ware, red ware and black slipped ware. KW

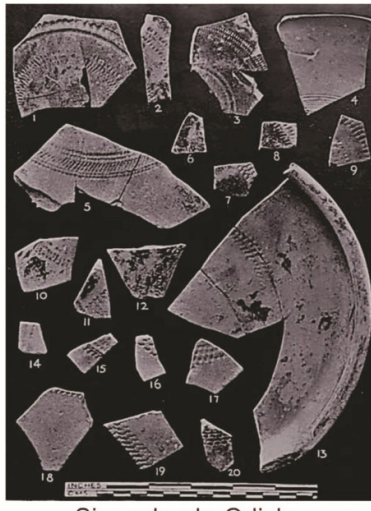

Sisupalgarh, Odisha

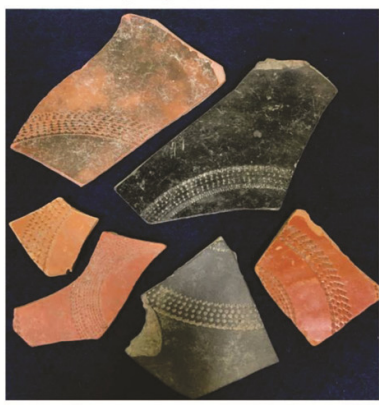

Alagankulam, Tamil Nadu

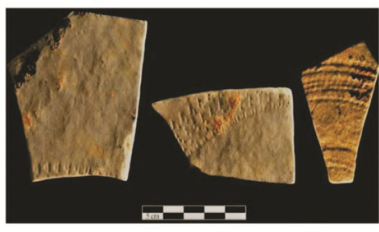

Pattanam, Kerala

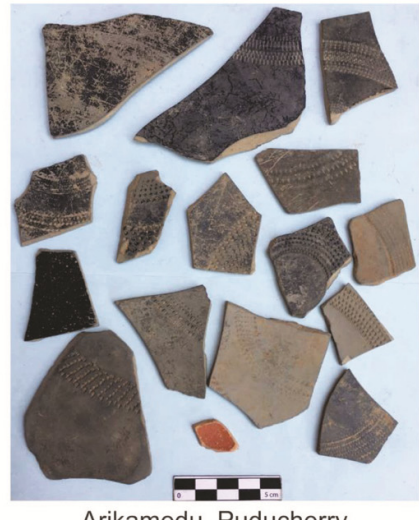

Arikamedu, Puducherry

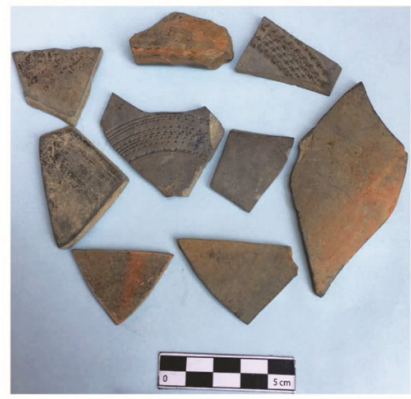

Kondapur, Andhra Pradesh

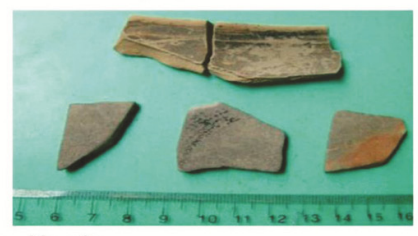

Figure 2. Rouletted ware from different sites of India.

CURRENT SCIENCE, VOL. 116, NO. 8, 25 APRIL 2019 
was found for the first time at Sisupalgarh and Jaugada, both are in Odisha ${ }^{29-31}$ (Figure $3 a$ and $b$ ), belonging to the early centuries of the Christian era. Consequently, this pottery was reported from many coastal and hinterland sites of Odisha (Figure 4), Andhra Pradesh, and the Gangetic valley of Bengal ${ }^{16,32-34}$. A black granite (reliquary) knobbed bowl was found in the ruins of a monastery in the north of Taxila, and high tin bronze knobbed bowls came from Nilgiri, Tamil Nadu, in megalithic context ${ }^{35-37}$. Excavations at Ban Don Ta Phet and Khao Sam Kaeo in Peninsular Thailand have yielded knobbed vessels made of high tin bronze ${ }^{38,39}$.

Stamped ware pottery is stamped with mostly linear and geometric combinations such as squares, triangles, double or triple parallel lines, including floral and faunal designs. The exterior of the whole pottery is decorated which extends up to the neck portion. Mostly, stamped
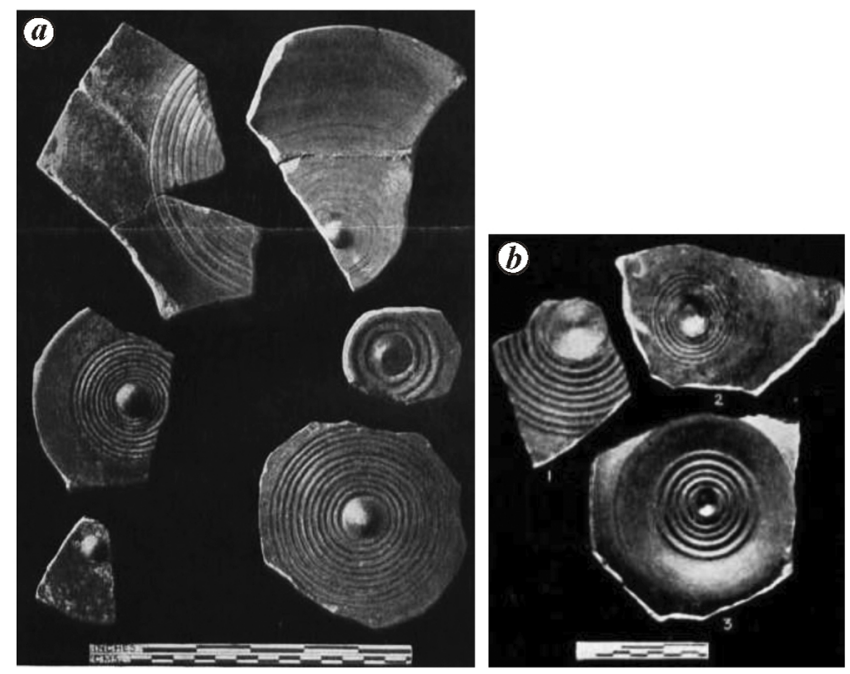

Figure 3. Knobbed ware (KW) found from (a) Sisupalgarh and (b) Jaugada, Odisha. (Photograph: ASI).

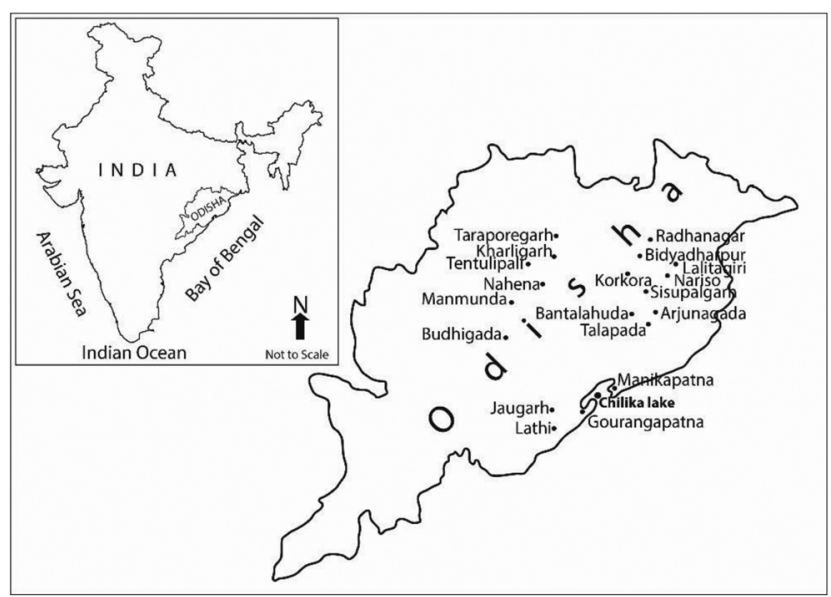

Figure 4. Knobbed ware sites along coastal and hinterland region of Odisha. ware was reported from the coastal sites of Arikamedu $^{40,41}$ in Tamil Nadu, Jaugada in Odisha ${ }^{30}$, Kottapatnam $^{42}$ and Motupalli ${ }^{43}$ in Andhra Pradesh along the east coast of India. The tradition of stamping the whole body of the pot (except neck and rim) was never prevalent in India, whereas it was widespread in China and Southeast Asia. Therefore, it is believed that the stamped ware found in the coastal sites might have been imported, probably from Southeast Asian countries or produced locally after learning technology. However, a comprehensive study is essential to draw conclusions. The date of stamped ware differs from site to site, for instance in Jaugada, stamped ware was reported in association with punch-marked coins (PMC) datable to the 3rd and 2nd century $\mathrm{BCE}^{30}$. In the case of Arikamedu the stamped ware was assigned to between $25 \mathrm{BCE}$ and $25 \mathrm{CE}$. In Kottapatnam abundant quantity of stamped ware was found in sand deposits; therefore it is difficult to determine the period ${ }^{44}$ because this pottery also occurs in medieval context.

Across the Indian subcontinent, Roman amphorae of the Eastern and Western Mediterranean as well as the Red sea types were found from many sites of India, and mainly wine, olive oil and garum were transported in these vessels. Among amphorae types, Dressel 2-4 wine amphora (1st to 3rd century CE) and Amphore Egyptienne 3 (AE3) (1st century BC) were commonly reported from Arikamedu, Alagankulam Hathab and Pattanam, whereas AE3 was found only at Arikamedu and Pattanam ${ }^{45-48}$. The other type of amphorae of the Mesopotamian origin without handles, barrel-shaped body, narrow base was known as torpedo jar, reported from many sites of India, but these torpedo jars have also been identified as Roman amphorae. In addition to amphorae, the terra sigillata, the fine moulded and decorated ware, which was imported from the Eastern and Western Mediterranean regions have also been found in Arikamedu, Alagankulam and Pattanam and many sites of southern and western India. The terra sigillata was brought to India as their personal belongings by the Roman traders, but not as an item supplied in trade ${ }^{49}$. Other Roman artefacts imported to India were Roman glasses, glass vessels, lamps, mirrors, metal statuettes. Most of these Roman objects were discovered in northwestern, western and southern India.

Roman amphorae and Roman coinage are the most critical items for understanding the exchanges between the Roman empire and India. The Roman coins found in India have been dated more precisely by the name of the emperor and their reign period, and it has been agreed that the Roman contacts began under Augustus (31 BCE$14 \mathrm{CE}$ ) and continued up to the time of Nero, then it was revived in the 5 th century CE. However, Turner ${ }^{50}$ urged that the Republican silver denarii arrived in India before Augustus and the Roman coins are the most prolific and largely studied along with other findings and 6000 denarii have been reported from South India. If one includes Late 
Roman copper coinage, this number is substantially boosted with over 4000 from Karur and Madurai in Tamil $\mathrm{Nadu}^{51}$

During Manikapatna excavations, a potsherd was found which has been identified as an amphora sherd ${ }^{52}$. Similarly, one more sherd of an amphora was also found from Karanji village, close to Jayarampur on the border of Odisha and West Bengal; it is now in a private collection $^{53}$. These finds are very few and it is not certain whether or not these are amphora sherds; therefore further studies are required to ascertain their origin and provenance. The Roman gold coins of Gordian, Constantine and other rulers were found at Bamanghati of Mayurbhanj, Odisha ${ }^{50,54}$. Twenty-three gold coins were reported from Gumada in 1928 and sent to Madras Museum. Among the twenty-three gold coins of Gumada, only one coin appears to be the genuine coin of Septimius Severus $^{50,55}$ and the remaining are considered counterfeited ones.

Similarly, four dinars, three of Augustus and one of Tiberius coins were found in undescribed circumstances from Kotapad of Odisha. All these eight coins are datable to the 1 st century BCE-2nd century CE (Figure 5) ${ }^{50}$. Except one, all other Roman coins of Odisha are imitated. Roman bullae (an amulet with Roman portraits worn around the neck like a locket) have also been recorded from the excavations of Sisupalgarh, Manikapatna and Radhanagar ${ }^{29,33,56}$.

The above discoveries suggest that the Roman findings are limited in Odisha. Moreover, the authenticity of these findings should be understood unmistakably; whether these discoveries belong to the Roman period or not; and how did these findings come to Odisha? It is known that in ancient times trade was based on barter system and then coins were introduced. The local products were exchanged with both essential and luxury items at ports and trade/urban centres among the traders. In this context, the mariners of Odisha might have exchanged their products with locals as well as south Indian traders. But what kind of Roman artefacts were brought to Odisha for exchange is not known. As of now it is well known that the Roman objects found in Odisha are limited and insignificant and their authenticity needs to be studied further. The Roman findings such as amphorae, Roman coins,
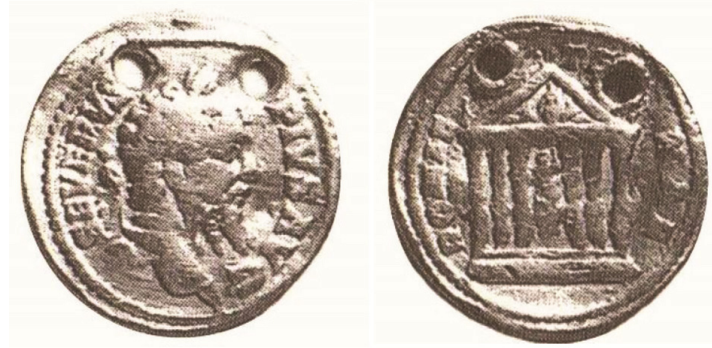

Figure 5. Roman coins used as ornament found from Gumada, Odisha. (Photograph: OIMSEAS, after Paula Turner ${ }^{50}$.) terra sigillata and other artefacts have been more abundantly recorded in Tamil Nadu, Andhra Pradesh, Maharashtra, Kerala and Gujarat in comparison with Odisha. Moreover, the Roman coins and amphorae sherd which are reported from Odisha need to be re-examined because the amphora sherd of Manikapatna (Figure 6) is a piece of a salt-glazed jar datable to the medieval period ${ }^{47}$ or could be a sherd of a mercury jar, but certainly not an amphora sherd. During the recent explorations of Khalkatapatna, a contemporary to Manikapatna port, a sherd of mercury jar found which is datable to the medieval period ${ }^{57}$, even in shape and design these sherds resemble.

Even, the amphorae found in West Bengal are doubtful about their origin, it could be of West Asian origin datable to the early medieval period. The jars which are displayed as amphorae at the Tamralipti Museum are wrongly labelled. Similarly, the double handled jar ${ }^{58}$ of Karanji village, nearer to Jayrampur of West Bengal (Figure 7) is also not an amphora. Amphora like jars were found from Chandraketugarh, Tamralipti, Harinarayanpur and Atghara along with RW, which are not amphorae. None of the classical texts makes any direct reference to maritime contacts between the ports of Bengal coast and the Roman Empire, nor have any Roman coins been reported from the West Bengal coast. Therefore, the jars displayed at Tamralipti Museum and Karanji village should be re-examined, and the Roman gold coins found at Bamanghati also need to be cross-examined. However, recently, an Aqaba (Aila-Axum) amphora was found in Kalindi village of East Medinipur district of West Bengal. It suggests the maritime contacts between Bengal coast and the Red Sea and the Mediterranean region during early medieval period ${ }^{59}$.
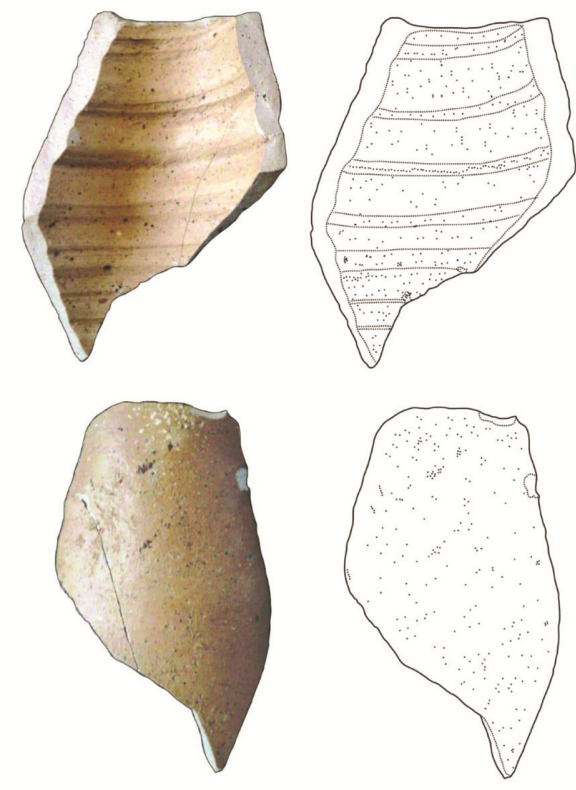

Figure 6. Amphora sherd from Manikapatna. (Photograph: OIMSEAS.)

CURRENT SCIENCE, VOL. 116, NO. 8, 25 APRIL 2019 


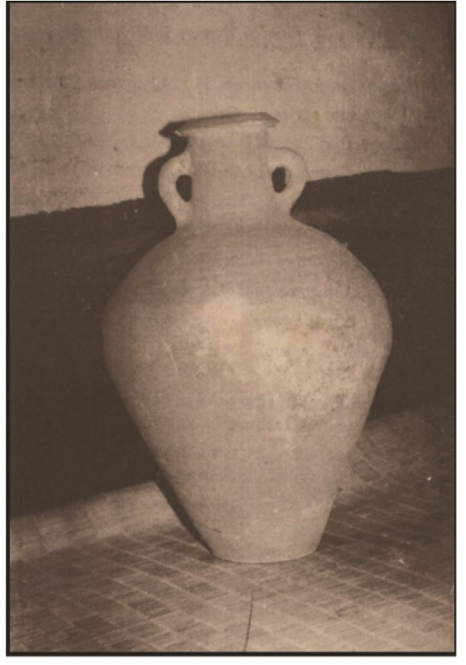

Figure 7. Amphora from Karanji village, West Bengal. (Photograph: OIMSEAS, after Sengupta ${ }^{58}$.)

Roman mariners did not reach Odisha coast for trade and commerce because, except ivory, no other products of Odisha were required for the Romans. The Romans were more interested in Indian spices, textiles, silk, etc. Indian gemstones, spices, aromatic wood, sandalwood, silk, cotton, gems, ivory, textiles were in great demand in the Roman market. Moreover, Roman mariners directly reached the western and southern coasts of India crossing the Arabian Sea. The summer (Southwest) monsoon winds were favourable to sail up to the Indian coast. During this period, sailing vessels were more dependent on winds and currents which were seasonal. And sailing to Odisha beyond Tamil Nadu or Kerala coast would require longer time, probably which was not feasible for Roman mariners. Hence, it is believed that the merchandise of Odisha was transported to the southern and western coasts either by over land routes or by local mariners. Thus, it can be suggested that Odisha had probably indirect contacts with Romans.

Moreover, Periplus suggested that Roman ships did not sail up to the Odisha and Bengal coasts because of sailing schedules. It was proposed that ships from the Egyptian ports on the Red sea coast usually began their voyage for South Asia in July and reached South Indian ports in September $^{60,61}$ and their return journey had to start in November with the aid of Northeast monsoon (trade) winds. The Roman merchants had very little time for selling their merchandise and loading ships with goods available from the local markets of Tamil Nadu or Kerala coast. Hence sailing down to Odisha or Bengal coast was difficult because it entailed the risk of missing the northeast trade winds. Furthermore, Roman mariners did not visit the Southeast Asian countries to get spices because of the time factor, but the spices of Southeast Asia were brought by the mariners of south India and the Romans collected them from Arikamedu. Moreover, Strabo
(63 BCE-24 CE) stated that 'the merchants of the present day, who sail from Egypt to India by the Nile and the Arabian Gulf, have seldom made a voyage as far as the Ganges ${ }^{, 62}$.

Periplus referred to the diamond of Sabarae which is identifiable nearer to Sambalpur and the ivory of Dosarene (perhaps refers to Odisha) ${ }^{54,60,61}$ which was considered the best Indian ivory. Both, the ivory and diamond were praised in Rome, these were luxury items, and their demand was less than spices. Further, Periplus ${ }^{57}$ suggests that the diamonds from India including Sabarae (Sambalpur) of Odisha was brought to Muzuris and Nelcynda ports along the west coast of India from where it was exported to the Roman empire. It is not clear who were the traders bringing the diamond and ivory from Odisha to Muzuris and Nelcynda. There could be possibilities that middlemen were involved in this trade or merchants of Odisha might have engaged in this activity.

It is not comprehensible, how the Roman coins, amphorae and other archaeological artefacts were found in Odisha? All these artefacts have been referred to as Roman period findings ${ }^{1,2,52,56}$ after their re-examination now it is proved that these are not amphora sherds.

With regard to direct maritime contacts between Odisha and the Roman Empire, no tangible evidence is available till date. But the materials from Odisha might have been carried away by the middlemen. However, future explorations and excavations may bring some new information which will enhance the knowledge and change the current state of understanding presented here; because very limited early historic sites of Odisha so far have been excavated. In the absence of direct and ample evidence, it is too early to corroborate that Odisha had direct contacts with Romans. Moreover, Periplus suggests that ships of the Red sea coast reached ports of South India in September and returned in November during the beginning of Northeast monsoon winds and they had limited time to visit other areas. This denotes that Roman traders could not directly go up to the Odisha and Bengal coasts. The Romans may have had no direct contacts with Odisha, but they were aware of ivory and diamond of Odisha. In all probability, some of the Romans might have visited Odisha or they were aware of the source and that is why Periplus mentioned about the quality ivory of Odisha which was highly praised. Precisely, it can be mentioned that so far no amphorae have been reported from Odisha and there were no direct maritime trade contacts between Odisha and the Romans during the early historical period. The counterfeit Roman coins were brought to Odisha to procure ivory as stated by Periplus or people of Odisha might have brought ivory to Muzuris and Nelcynda and exchanged them for Roman coins. However, the authenticity of the coins should also be established. The present study provides an opportunity for future researches and debates on the maritime contacts between Odisha and the Roman empire. 
1. Behera, K. S. (ed.), Kalinga-Indonesian Cultural Relations, OIMSEAS, Bhubaneswar, 2007.

2. Behera, K. S. (ed.), Maritime Heritage of India, Aryan Books International, New Delhi, 1999.

3. Patra, B., Maritime Trade and Overseas Activities of Early India Odishan Perspective, Aryan Books International, New Delhi, 2013.

4. Tripati, S., Maritime Archaeology: Historical Descriptions of the Seafarings of the Kalingas, Kaveri Books, New Delhi, 2000.

5. Tripati, S., Early maritime activities of Orissa on the east coast of India: Linkages in trade and cultural developments. Man Environ., 2002, 27, 117-126.

6. Ghosh, A. (ed.), An Encyclopaedia of Indian Archaeology, Munshiram Manoharlal, New Delhi, 1989, vol. 1, pp. 251-255.

7. Roy, T. N., A Study of Northern Black Polished Ware Culture, Ramanand Vidya Bhawan, New Delhi, 1986.

8. Roy, T. N., The Ganges Civilization, Ramanand Vidya Bhawan, New Delhi, 1983.

9. Verma, G. and Yadav, R., Dating of Northern black polished ware culture in the light of recent excavations. In Pura-Jagat, Indian Archaeology, History and Culture in Honour of Shri Late J. P. Joshi (eds Margabandhu, C. et al.), Bharatiya Kala Prakashan, Delhi, 2012, pp. 178-181.

10. Coningham, R., Manuel, M. and Shoebridge, J., Reconstructing networks of trade and exchange in the Indian Ocean during the early historic period: Case studies from Anuradhapura (Sri Lanka). In Imperial Rome, Indian Ocean Regions and Muziris (ed. Mathew, K. S.), Manohar Publishers, New Delhi, 2015, pp. 31-52.

11. Sarma, I. K., Indian seafaring traditions: archaeological perspectives. In An Integrated Approach to Marine Archaeology (ed. Rao, S. R.), Society for Marine Archaeology, NIO, Goa, 1997, pp. 95-101.

12. Sarma, I. K., Ceramics and maritime routes of India: new evidence. Puratattava, 1990-91, 21, 37-42.

13. Coningham, R., Beyond and before the Imperial Frontiers: Early historic Sri Lanka and the origins of Indian Ocean trade. Man Environ., 2002, 27, 99-108.

14. Manatunga, A., The first urbanisation of Sri Lanka: an investigation into nagara sites referred to in the early Brahmi inscriptions. Bull. Indo-Pacific Prehistory, 1997, 16, 49-55.

15. Parker, H., Ancient Ceylon, Asian Educational Services, New Delhi, 1984

16. Jahan, S. H., Archaeology of Wari-Bateshwar. Ancient Asia, 2010, 2, 135-146.

17. Jahan, S. H., Early maritime trade network of Bengal. Man Environ., 2002, 27, 127-138.

18. Ardika, I. W., Ancient trade relation between India and Indonesia. In Maritime Heritage of India (ed. Behera, K. S.), Aryan Books International, New Delhi, 1999, pp. 80-89.

19. Bouvet, P., Preliminary study of Indian and Indian style wares from Khao Sam Kaeo (Chumphon, Peninsular Thailand), FourthSecond Centuries BCE. In Early Interactions between South and Southeast Asia: Reflections on Cross-Cultural Exchange (eds Manguin, P. Y., Mani, A. and Wade, G.), ISEAS, Singapore, 2011, pp. 47-82.

20. Avanzini, A. (ed.), Along the Aroma and Spice Routes. The Harbour of Sumhuram, its Territory and the Trade between the Mediterranean, Arabia and India, Pontedera, Pisa, 2011.

21. Avanzini, A., The port of Sumhuram (KhorRori): New data on its history. In Imperial Rome, Indian Ocean Regions and Muziris (ed. Mathew, K. S.), Manohar Publishers, New Delhi, 2015, pp. 179-205.

22. Pavan, A., Trade and commercial routes along the Indian Ocean from the early centuries $\mathrm{BC}$ to the beginning of Christian era: new lights from the Indian pottery discovered at Sumhuram (Sultanate of Oman). In South Arabia and its Neighbours: Phenomena of Intercultural Contacts (ed. Gerlach, I.), Reichert Verlag, Wiesbaden, 2015, pp. 121-134.
23. Pavan, A. and Schenk, H., Crossing the Indian Ocean before the Periplus: a comparison of pottery assemblages at the sites of Sumhuram (Oman) and Tissamaharama (Sri Lanka). Arabian Archa. Epigra., 2012, 23, 191-202.

24. Schenk, H., Role of ceramics in the Indian Ocean maritime trade during the Early Historical Period. In Maritime Contacts of the Past Deciphering Connections amongst Communities (ed. Tripati, S.), Delta Book World, New Delhi, 2015, pp. 143-181.

25. Schenk, H., The dating and historical value of rouletted ware. Zeitschrift fur Archaologie Au Bereuropaischer Kulturen, 2006, 1, $123-152$.

26. Tomber, R., Indian fine wares from the Red Sea coast of Egypt. Man Environ., 2002, 27, 25-31.

27. Sidebotham, S. E., Berenike and the Ancient Maritime Spice Route, University of California Press, California, 2011.

28. Rajan, K., Early Writing System-A Journey from Graffiti to Brahmi, Pandya Nadu Centre for Historical Research, Madurai, 2015.

29. Lal, B. B., Sisupalgarh 1948: an early historical fort in Eastern India. Ancient India, 1949, 5, 62-105.

30. IAR, Indian Archaeology: A Review, Archaeological Survey of India, New Delhi, 1956-57, pp. 30-31.

31. Ghosh, A. (ed.), An Encyclopaedia of Indian Archaeology, Munshiram Manoharlal, New Delhi, 1989, vol. 2, pp. 412-414.

32. Mohanty, R. K., Smith, M. L. and Matney, T., Excavations and Geophysical survey at the Early Historic town Talapada, Odisha (2013). Man Environ., 2014, 39, 53-63.

33. Patnaik, S. K., Excavations at Radhanagar (Kanika), An Early Historical Buddhist Site, Odishan Institute of Maritime and Southeast Asian Studies, Bhubaneswar, 2015.

34. Mishra, B., Theoretical aspects of early historic urbanism vis-à-vis the early urban centres of Orissa. In Settlement and Urbanization in Ancient Orissa (eds Mishra, B. and Dandasena, P. K.), Indological Book Seller, Kolkata, 2010, pp. 51-76.

35. Glover, I. C., The role of India in the late Prehistory of Southeast Asia. J. Southeast Asian Arch., 1998, 18, 21-49.

36. Glover, I. C., Early trade between India and Southeast Asia: a link in the development of a world trading system. Occasional Paper No. 16, The University of Hull, London, 1990, pp. 1-45.

37. Srinivasan, S., High tin bronze working in India, the bowl makers of Kerala. In Archaeometallurgy in India (ed. Tripathi, V.), Sharada Publishing House, New Delhi, 1998, pp. 241-250.

38. Glover, I. C. and Bellina, B., Ban Don Ta Phet and Khao Sam Kaeo: The earliest Indian contacts re-assessed. In Early Interactions between South and Southeast Asia: Reflections on CrossCultural Exchange (eds Manguin, P. Y., Mani, A. and Wade, G.), ISEAS, Singapore, 2011, pp. 17-46.

39. Glover, I. C. and Bennett, A., The high-tin in bronzes of Thailand. In Scientific Research into Ancient Asian Metallurgy, Proceedings of the Fifth Forbes Symposium, Freer Gallery of Art at the Freer Gallery (eds Paul, J., McCarthy, B. and Douglas, J. G.), Archetype Books, London, 2012, pp. 101-114.

40. Begley, V., Arikamedu reconsidered. Am. J. Archa., 1983, 87, $461-481$.

41. Wheeler, R. E. M., Ghosh, A. and Deva, K., Arikamedu: An IndoRoman trading station on the East coast of India. Ancient India, 1946, 2, 17-124.

42. Rao, K. P., Early trade and contacts between South India and Southeast Asia (300 BC-AD 200). East West, 2001, 51, 386-394.

43. Reddy, P. K. M., Maritime trade of early South India new archaeological evidences from Motupalli, Andhra Pradesh. East West, 2001, 51, 143-156.

44. Rao, K. P., Kottapatnam - a South Indian Port trading with Eastern lands. In Search of Chinese Ceramic Sherds in South India and Sri Lanka (ed. Karashima, N.), Taisho University Press, Tokyo, 2004, pp. 11-15. 
45. Tomber, R., Beyond western India: The evidence from imported amphorae. In Migration, Trade and Peoples, Part I: Indian Ocean Commerce and the Archaeology of Western India (eds Tomber, R., Blue, L. and Abraham, S.), The British Association for South Asian Studies, London, 2010, pp. 42-57.

46. Tomber, R. and Williams, D. F., Egyptian amphorae in Britain and the western provinces. Britannia, 2000, 31, 41-54.

47. Tomber, R., Indo-Roman Trade from Pots to Pepper, Duckworth, London, 2008.

48. Tomber, R., Indo-Roman trade: the ceramic evidence from Egypt. Antiquity, 2000, 74, 624-631.

49. Gurumurthy, S., Ceramic Traditions in South India, Madras University Press, Madras, 1981.

50. Turner, P. J., Roman Coins from India, Special Publication No. 22, Royal Numismatic Society, London, 1989.

51. Sridhar, T. S., Suresh, S. and Sundararajan, N., Roman Coins in the Government Museum, Chennai, 2011.

52. Pradhan, D., Manikapatna Excavations (1989-1993): Cultural affinities of Southeast Asia through archaeological evidences. In Kalinga-Indonesian Cultural Relations (ed. Behera, K. S.), OIMSEAS, Bhubaneswar, 2007, pp. 71-95.

53. Acharya, P., Studies in Orissan History, Archaeology and Archives, Student's Store, Cuttack, 1969.

54. Warmington, E. H., The Commerce between the Roman Empire and India, Vikas Publishing House, New Delhi, 1974.

55. Harinarayana, N., The Treasure Trove Act and the Governmen Museum, Madras. In Museum and Museology: New Horizons (Essays in honour of Dr Grace Morley on her 80th Birthday (eds Dwivedi, V. P. and Pant, G. N.), Agam Kala Prakashan, New Delhi, 1980, pp. 275-280.

56. Pradhan, D., Mohanty, P. and Mishra, J., Manikapatna: an ancient and medieval port on the coast of Orissa. In Archaeology of Orissa (eds Basa, K. K. and Mohanty, P.), Pratibha Prakashan, New Delhi, 2000, pp. 473-494

57. Tripati, S., Mani Murali, R., Jaya Kumar, S., Pradhan, A. K., Behera, R. P. and Choudhury, R., Khalkattapatna port: the lost archaeological heritage of Odisha, east coast of India. Curr. Sci., 2015, 109, 372-377.

58. Sengupta, G., Archaeology of coastal Bengal. In Tradition and Archaeology Early Maritime Contacts in the Indian Ocean (eds Ray, H. P. and Salles, J. F.), Manohar, New Delhi, 1996, pp. 115-127.

59. Gangopadhyay, K., Selvakumar, V. and Maiti, A., A short note on an unique Early Medieval Aqaba Amphora from coastal East Medinipur District, West Bengal. J. Asiatic Soc., 2017, 59, 109-124.

60. Casson, L., The Periplus Maris Erythraei, Princeton University Press, Princeton, 1989.

61. Schoff, W. H., Periplus of the Erythraean Sea, Oriental Books, New Delhi, 1974.

62. McCrindle, J. W., Ancient India as Described in Classical Literature, Eastern Book House, Patna, 1987.

ACKNOWLEDGEMENTS. We thank the Director, CSIR-National Institute of Oceanography, Goa, for permission to publish this paper. We also thank Prof. Romila Thapar, Dr Robert Tomber, Dr R. K. Mohanty and Dr Shahnaj Husne Jahan for sharing views on Odisha and Roman contacts. We are grateful to the anonymous reviewers for their comments and valuable suggestions for improvement of the manuscript, and to ASI, Department of Archaeology, Tamil Nadu, KCHR, Kerala, M. Ramesh, Puducherry for the RW photographs and to OIMSEAS for coins, and other pottery; to colleagues for their cooperation and suggestions in completing the paper and Sujal Bandodkar for figures. This is NIO's contribution no. 6347.

Received 20 November 2017; revised accepted 25 January 2019

doi: $10.18520 / \mathrm{cs} / \mathrm{v} 116 / \mathrm{i} 8 / 1391-1397$

\section{Optimized culture conditions for} enhanced recovery of exopolysaccharide from Pseudolagarobasidium acaciicola: a novel fungus isolated from the fruit body of Russula nigricans, a wild edible mushroom of Odisha, India

\section{Smita Behera and Nibha Gupta*}

Plant Pathology and Microbiology Division,

Regional Plant Resource Centre, Bhubaneswar 751 015, India

Fungal exopolysaccharides (EPS) are becoming important due to their multifarious applications with different structural forms and easy recovery. The objective of this study was to optimize submerged culture condition of a new fungal isolate Pseudolagarobasidium acaciicola obtained from fruit body of an edible mushroom, Russula nigricans. The study analyses the optimization of different parameters for enhanced production of EPS by one factor-at-a-time (OFAT) method. The influence of incubation period, initial pH value, temperature, mode of culture (static shake), culture vessel, carbon and nitrogen sources, and enhancers was studied. OFAT method revealed pH 6 with 7 days incubation statically and in dark in $150 \mathrm{ml}$ Erlenmeyer flask, chemical factors like sabouraud dextrose $\mathrm{HiVeg}$ broth medium, xylose, yeast extract, tryptophan, $\mathrm{K}_{2} \mathrm{HPO}_{4}, \mathrm{CaCl}_{2}$ and vitamin $\mathrm{C}$ as good conditions and components for maximum biomass and EPS production. Optimized medium developed in this study was a combination of the individually screened nutrient component, estimated the maximum EPS $(1002.3 \pm 189.72 \mathrm{mg} / \mathrm{l})$ which was later expelled to $1468.1 \pm 227.86 \mathrm{mg} / \mathrm{l}$ after addition of olive oil and Tween 80 at a concentration $250: 50 \mu \mathrm{l}$ $\mathrm{v} / \mathrm{v}$, which was much higher, and reported first time from this fungus (it means that early when medium was formulated with different chemical components we got the optimized medium giving $1002.3 \mathrm{mg} / \mathrm{l}$ of EPS but when addition of oils was performed we got more amount, i.e. $1468.1 \mathrm{mg} / \mathrm{l}$ ). EPS production in a new medium might facilitate its industrial-scale production and use as a bioactive product for the welfare of mankind.

Keywords: Exopolysaccharide, optimization, Pseudolagarobasidium acaciicola, submerged culture.

MANY microbes produce bioactive polysaccharides which are high-molecular-weight polymers composed of long chains of monosaccharide units linked with glycosidic bonds and release the constituent monosaccharides/ oligosaccharides on hydrolysis ${ }^{1-3}$. Polysaccharides are diversified due to their structure, properties, and

*For correspondence. (e-mail: nguc2003@yahoo.co.in) 